\title{
Strategy for Improving Cooperative Institutional Quality in Semarang
}

\author{
Khasan Setiaji, Yuan Arsinta \\ Economic Faculty, Universitas Negeri Semarang \\ Email: setiaji@mail.unnes.ac.id, arsintayuan@gmail.com
}

Received: September 28, 2017; Accepted: December 5, 2017; Published: February 2, 2018

Permalink/DOI: http://dx.doi.org/10.17977/um002v10i12018p056

\begin{abstract}
The existence of many problematic cooperatives has indicated the lack quality of their institution. Therefore, it is important to prioritize the assistance from the government. This research aims to identify a strategy to improve the quality of the institutions at the Board for Cooperative and Small Enterprises in Semarang. This research employs qualitative method focusing on the strategies for improving the quality of cooperative institutions. The research shows that they use some strategies: (1) socialization to community; (2) establishment of cooperative; (3) assistance from facilitators for cooperatives at the subdistrict level consisting of evaluation, inventory, and counseling; (4) coordination among facilitators; (5) formulating assistance strategies; and (6) evaluation.
\end{abstract}

Keywords: Strategy, Institutions, Cooperative, Small Enterprises JEL Classification: G20, Q13

\section{INTRODUCTION}

The opportunities are needed by society in Indonesia to express their aspirations in many aspects of life to achieve national welfare. In an economic democracy, society should be given opportunities to create something in the form of ownership and get sharing system to earn the income fairly (Hatta, 2015). Cooperatives are based on the values of self-help, self-responsibility, democracy, equality, equity, and solidarity. In the tradition of their founders, co-operative members believe in the ethical values of honesty, openness, social responsibility and caring for others (International Co-operative Alliance, 2015)

The cooperative plays important role in creating its ideal modernity by keeping its principles. This is due to the democracy values owned by Indonesian representing the principles values that are equality, fairness, and self-help collectively (Nasution, 2008:42). Hence, cooperative can be a way to provide a better life for its members and society widely and strengthen its democracy (Nasution, 2008:53). Cooperatives are distinguished from other organizations in that member use, or patronage is linked to control of the enterprise, rather than the degree of monetary investment. Cooperatives also differ from nonprofit organizations, which do not issue stock and do not have individual owners at all (Lund, 2013; Hansman, 2014).

The cooperatives are referred to as a "hybrid" form of social enterprise that can move between social and economic purposes depending on the needs identified within their Member Value Proposition (MVP). As with any 
community-based enterprise, the co-op is built on the skills inherent within its membership and is dependent on their participation, to achieve a multiplicity of goals that can be economic or social in nature (Edoho, 2015; Mazzarol, 2016). The development of Indonesian cooperative is illustrated in table 1.

Table 1. The Development of Cooperative in Indonesia year 2013-2016

\begin{tabular}{|c|c|c|c|c|c|}
\hline 1 & Number of Cooperatives & Unit & 203701 & 209488 & 212135 \\
\hline 2 & The growth of Cooperative & percentage & 4.84 & 2.84 & 1.26 \\
\hline 3 & Number of Active Cooperatives & Unit & 143007 & 147249 & 150223 \\
\hline 4 & $\begin{array}{l}\text { Percentage of Active } \\
\text { Cooperatives from the Total } \\
\text { number of Cooperatives }\end{array}$ & Percentage & 70,20 & 70,29 & 70,81 \\
\hline 5 & $\begin{array}{l}\text { The Growth of Active } \\
\text { Cooperatives }\end{array}$ & Percentage & 2,65 & 2,97 & 2,02 \\
\hline 6 & $\begin{array}{l}\text { Number of Active Members of } \\
\text { Cooperatives }\end{array}$ & Persons & 35258176 & 36443953 & 37783160 \\
\hline 7 & $\begin{array}{l}\text { Growth of Members of Active } \\
\text { Cooperatives }\end{array}$ & Percentage & 4,10 & 3,36 & 3,67 \\
\hline 8 & Capital & IDR million & 170376863 & 200662817 & 242445396 \\
\hline 9 & Growth of Capital & Percentage & 65,69 & 17,78 & 20,82 \\
\hline 10 & Business Volume & IDR million & 125584976 & 189858672 & 266134619 \\
\hline 11 & Growth of Business Volume & Percentage & 5,37 & 51,18 & 40,18 \\
\hline 12 & $\begin{array}{l}\text { Different of Business Result } \\
\text { (SHU) }\end{array}$ & IDR million & 8110180 & 14898647 & 17320664 \\
\hline 13 & The Growth of SHU & Percentage & 21,74 & 83,70 & 16,26 \\
\hline
\end{tabular}

Source: BPS (2017)

Based on the data, even though the quantity of the cooperatives in Indonesia is positive, there is still a need to improve the quality of the cooperatives. The cooperatives should have good quality so that they can become independent and healthy. Factually, reformation on cooperatives can become a way to be implemented by the government of Indonesia through three steps: rehabilitation, reorientation, and development (Kementerian Koperasi dan Usaha Kecil dan Menengah, 2015). The amount of active cooperatives indicates that there is a challenge faced by cooperatives such as the level of capability, skills, expertise, human resource development management, entrepreneurship, marketing and finance (Suprayitno, 2007).

In an effort to encourage the development of SMEs in Indonesia is required funding one of which is cooperative. Cooperative had a positive effect for cooperative members who borrow especially for the self-employed (Ardyani, 2015).

The existence of deviant practices in cooperatives causing trauma for society to cooperate. The cause of the deviation is the lack of knowledge for cooperatives in conducting cooperative practices in the right and proper way and there is the less optimum role of supervision (Sukidjo, 2008:1). Therefore, the government is required to improve community access to economic opportunities. This can be conducted in two ways: improving the quality of human resources and access to the market, capital, technology, and organization (Tjakrawerdaja, 2014: 181). In Semarang, the number of non-active cooperatives amounted to $11.28 \%$. 
This number is not bigger than the ones on regencies/cities in Central Java province but there are many deviant practices on the principles of cooperatives.

\section{METHOD}

This research used a qualitative approach and its focus is on the strategies to improve the quality of cooperative institutions: cooperative licensing and institution, cooperative empowerment, supervision and inspection conducted by Board Cooperatives and Small and Medium Enterprises in Semarang focusing on the confirmator object that is Widya Lestari cooperative in Semarang. The data are taken using observation, interview, and documentation study. In this research, dependability and credibility tests with member check and source triangulation are used (Prastowo, 2012: 274).

\section{RESULT AND DISCUSSION}

The Board of Cooperatives and Micro Enterprises of Semarang plays a role to strengthen the local people-based economy and create conducive business climate. Therefore the board of Cooperatives and Micro Enterprises of Semarang behaves as a coach as well as a facilitator aiming to foster, empower and supervise the cooperative. The main focus of coaching and supervision is the institutional aspect, business aspect, and financial aspect. The description of the Strategy made by the board of Cooperatives and Micro Enterprises in Semarang to improve the quality of cooperative institutions is in Figure 1.

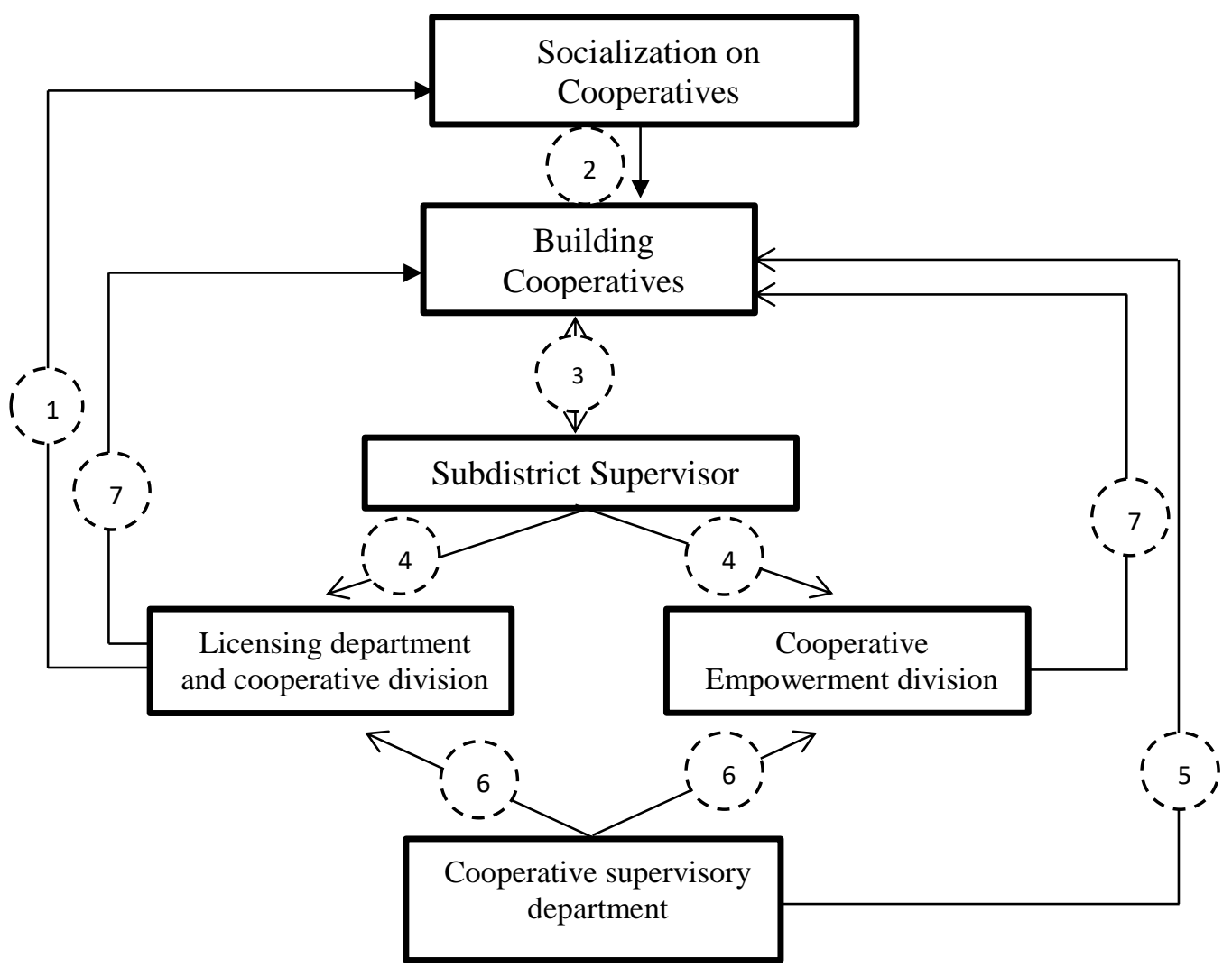

Figure 1. Strategy for Improving Quality of Cooperative Institution in Semarang 


\section{Socialization of Cooperative to Society}

Socialization is the first step to be carried out to create the spirit of cooperative and provide information on how to establish or join cooperatives. The socialization of cooperatives to the society in Semarang is carried out by the Licensing and Institutional division of Cooperatives every year. This socialization will raise awareness to the community as a prospective board, supervisors, and members of cooperatives to run cooperatives in accordance with the identity of the cooperative.

\section{Establishment of Cooperatives}

Communities regardless their participation in socialization will be accompanied by the Licensing and Institutional division of Cooperatives to establish cooperatives and obtain legalization. The cooperative legal entity can be proposed by an existing cooperative which does not have a legal entity yet or a newly established cooperative. Cooperatives that propose the legal entity must meet the requirements set by the government. The legalization of the deed of a cooperative legal entity is carried out by the Ministry of SMEs \& Cooperatives. While the board of Cooperatives and Micro Enterprises of Semarang has the right to issue business licenses for savings and loan cooperatives or the one that have a unit of savings and loan business. After the cooperative receives the legalization in the form of legal entity certificate, then the cooperative will get coaching from the cooperative supervisor at the subdistrict level.

\section{The supervisory activities by the supervisor of the cooperative subdistrict}

Administratively, the area of Semarang is divided into 16 districts, namely Banyumanik, Candisari, Gajahmungkur, Gayamsari, Genuk, Gunungpati, Mijen, Ngaliyan, Pedurungan, Semarang Barat, Semarang Selatan, Central Semarang, East Semarang, Semarang Utara, Tembalang, and Tugu. Each subdistrict has a cooperative supervisor. The cooperative manager of the subdistrict is under the command of the Institutional Section of Cooperatives and coordinates with the division of Cooperative Empowerment. The guidance implemented by the cooperative supervisor aims to improve the quality of cooperatives which include three aspects: the institutional aspects, business aspects, and financial aspects. The task of the cooperative of the subdistrict is to carry out evaluation, inventory, counseling, and guidance. While the duties of the cooperative at the subdistricts are:

1. Conducting evaluation of the routine reports and reports of RAT (Annual Meeting of the Members). This evaluation process aims to find out the performance of the cooperative during the certain period which then, the results become evidence as responsibility to the board, supervisor, and manager of cooperatives and to the members of the cooperative. From the report made by the cooperative, the problem can be found out.

2. Conducting inventory. This inventory is carried out once a year by sub-district supervisor. This inventory covers three aspects:

a. The cooperative institutional aspect consists of: (1) Name of Cooperative; (2) Number of Legal Entity and date, Amendment of Articles of Association and date, Number of Cooperative; (3) Name of Institution/Company; (4) CurrentAddress; (5) Business licensing; (6) 
Management which consists of Chairman, Secretary, Treasurer; (7) Supervisorconsists of Chairman and Member (8) Manager; (9) Employees; (10) Members, Prospective Members (11) Health Assessment; (12) Newest RAT date; (13) OrganizationsBook; (14) Training that has been joined by management/supervisor/manager; (15) Problems faced by cooperatives.

b. Aspects of cooperative business that cover businesses run by cooperatives. Then, subdistrict supervisor examines the business registered by the cooperative. If there is the difference between the report and the real fact, the subdistrict supervisor takes his role to provide coaching and assistance to the cooperative.

c. The financial aspects of this cooperative consist of: (1) Assets; (2) Liabilities; and (3) Business Volume which includes savings and loan units and non-savings and loan businesses; and (4) Problems faced by cooperatives.

The findings of sub-district coaches will be considered by the Licensing and Institutional division of Cooperatives as well as the division of Cooperative Empowerment in formulating strategies for socialization, training, and training for cooperatives.

3. Providing counseling to cooperatives related to new information including the government regulations or policies.

4. The guidance carried out by the cooperative of the subdistricts is more directed to technical assistance on good and proper cooperative practices. In addition, to provide input and suggestions for the improvement of cooperatives, the coach is not allowed to deeply interfere. Subdistrict coaches play role only as facilitators for cooperatives who help to determine the future of the cooperatives for the members, administrators, and supervisors.

\section{Coordination of Subdistrict Supervisors with Division of Licensing and Institution and Division for Empowerment.}

The results of the evaluation and inventory from the cooperative subdistrict supervisor reported to the Licensing and Institutional Cooperatives as well as to the Empowerment Cooperatives division. It then becomes one of the considerations for each division to formulate strategies or steps to be taken to improve the quality of cooperatives. The findings of institutional aspects of the cooperative will then be reported to the Licensing and Institutional division of Cooperatives. Hence, activities can be then prepared to improve the quality of cooperative institutions. Meanwhile, the problems on business aspects and financial aspects of the cooperative will be reported to the division of empowerment cooperatives. Empowerment cooperative will provide more coaching for the running cooperatives (Azhari, 2017).

\section{The Relationship between Supervision and Inspection division with Cooperative}

The role and function of supervision and inspection board are important in the process of assistance, empowerment, and inspection. Semarang has conducted evaluation consisting of supervision, inspection, and assessment of cooperatives. This supervision is carried out having a direct visit to the cooperative or routine 
supervision, based on complaints from the community and the members of the cooperative or special supervision. This supervision process includes supervision on the institutional aspects, business aspects and financial aspects of the cooperative. After the subsequent supervision, the examination and assessment of cooperative activities are carried out.

If there is non-compliance of a cooperative, a warning is given and then, sanction if the cooperative does not improve itself. This sanction can be in the form of revocation of cooperative business license especially for savings and loans cooperatives or cooperatives which have a business unit. The revocation of cooperative legal entity leads to the removal of the legal entity from the Ministry of Cooperatives and SMEs as the institution issuing the deed of incorporation of a cooperative legal entity. While the Department of Cooperatives and Micro Enterprises role is limited to recommend the revocation of legal entities to the ministry.Some non-compliance often occurs in cooperatives in Semarang is the cooperative does not make prospective members to become members in certain maximum deadline. Some of the cooperatives do not perform RAT for two consecutive yearbooks, do not provide routine reports to the board. Some others are they do not extend their business license, the members lack the sense of belonging. Further, it is found that the management and supervisors do not understand their duties as a cooperative organization tool, and so on.

\section{Coordination between the Department of Supervision and Inspection of Cooperatives with the Department of Licensing and Institutional Cooperatives, and Department of Cooperatives Empowerment}

After knowing the problems of cooperatives such as non-compliance cooperatives, the Supervision and Inspection Cooperatives division will distribute the findings to the division of Licensing and Institutional Cooperatives and the division of Cooperative Empowerment. This will be one of the considerations for the division to determine further strategic steps to improve the quality of existing cooperatives in Semarang.

This result of the evaluation is distributed based on the finding existing in the cooperatives. For example, if the problems are related to the institution, the finding is informed to the division of licensing and institutional cooperatives. Then, if it is related to business and financial aspects, the information is given to cooperative empowerment division.

In general, the linkage between the division of Licensing and Institution, Empowerment, and Supervision and Inspection is in the process of its work. Where the division of Licensing and Institutional Cooperative is in charge of fostering and assisting community groups to establish cooperatives and the process of dissolution of the cooperative. After the establishment, then they are empowered by the division of Empowerment. This empowerment is carried out in the form of coaching to improve the ability of cooperative's human resources in running the activities. In the division of Supervision and Inspection, they play roles as evaluators of cooperative activities after the implementation of coaching and empowerment. Then, after the evaluation of the cooperative, a problem or non-compliance is found, it will be returned to the subdistrict cooperatives to find the solution. 


\section{Formulating Supervisory Strategies}

To formulate strategies and types of supervisory activities, department of licensing and cooperative institution and department for cooperative empowerment should consider the information from subdistrict supervisors and department of supervision and inspection of cooperatives. After acknowledging the problems at the field, effective and efficient strategies can be formulated to supervise cooperatives.

The strategic plan formulated by the department of licensing and cooperative institution should address to assist the human resources to enable them practicing the cooperatives principles. In addition, the supervisory in term of a cooperative institution such as the annual meeting for members (In Indonesian it is called Rapat Anggota Tahunan/RAT), and the cooperative obedience for the institution. Then, the department for cooperative empowerment addresses to improve the capability of the administrators, supervisors, and managers in managing cooperatives.

The strategic plans include programs such as socialization, training or education on technology. This socialization focuses more on giving information to make society involve in the cooperatives. The information is related to the regulation or its updated one. While training and education is addressed to improve the skills and capability of the human resources to practice the cooperative management. Then, technology assistance should focus on problemsolving of any problems in the cooperatives.

The assistance given to cooperatives from each department can be conducted by inviting them and direct visit to the offices by licensing and institution department and cooperative empowerment institution. The cooperative programs made by Board of Cooperative and Small Medium Enterprises in Semarang in 2017 are: 1) The improvement of cooperativemanagement such as basic management on cooperatives, training on cooperative management, socialization on the regulation of cooperatives, training for making financial report SAK ETAP; 2) the improvement of cooperative supervisory management such as training for cooperative supervisory management and risk management; 3 ) Development of cooperative business such as development of village unit cooperative, retail business development, and saving and loan department; 4) the improvement of cooperative control such as cooperative inspection, evaluation of the implementation of cooperative obedience, competition on cooperative achievement, and school cooperative competition; 5) Cooperative's health condition assessment; 6) cooperatives' day facilities such as ceremony on a cooperative day, achievement reward and/or cooperative figure/hero; cooperatives competition, discussion meeting on cooperatives' day; 7) facilities of cooperative institution such as cooperative assistance, cooperative revitalization, coordination meeting, cooperative institution improvement, coordination meeting of branch offices on saving and loan, and achievement motivation training; 8) socialization of cooperative institution to society, students' cooperative supervisory, and its establishment; 9) advocacy and cooperative assistance such as new regulation, the changes on articles of association, branch office advocacy, cooperative dissolution, and specific rules for cooperatives. 


\section{CONCLUSION}

The institution is a platform for people in implementing their authority to manage cooperatives. The improvement in the quality of the cooperative institution is expected to make cooperative stronger and independent. The strategies that can be used by Board of Cooperatives and Small and Medium Enterprises are: (1) socialization to society; (2) establishment of cooperatives; (3) supervisory activities at the subdistrict level by the supervisor such as evaluation, inventory, supervisory, and assistance; (4) coordination among supervisors; (5) formulating supervisory strategies; (6) evaluation.

\section{REFERENCES}

Ardyani, C.D. (2015). Peranan Koperasi Wanita Serba Usaha Setia Budi Wanita Jawa Timur Dalam Memberikan Pinjaman LPDB Kepada Wirausaha di Malang. Jurnal Ekonomi dan Studi Pembangunan, 7(2), 69-72.

Azhari., Syechalad, M.N., Hasan, I., \& Majid, M.S.A. (2017). The Role of Cooperative in the Indonesian Economy. International Journal of Humanities and Social Science Invention, 6(10), 43-46.

BPS. (2017). Statistik Koperasi Simpan Pinjam 2016. Retrieved from https://www.bps.go.id/.

Edoho, F.M. (2015). Entrepreneurship and Socioeconomic Development: Catalyzing African Transformation in the $21^{\text {th }}$ Century. African Journal of Economic and Management Studies, 6(2), 127-147.

International Co-operative Alliance. (2015). Guidance Notes to the Co-operative Principles.

Hansman, H. (2014). All Firms are Cooperative and so are Governments. Journal of Entrepreneurial and Organizational Diversity, 2(2), 1-10.

Hatta, M. (2015). Membangun Koperasi Dan Koperasi Membangun. Jakarta: Buku Kompas.

Kementerian Koperasi dan Usaha Kecil Dan Menengah (2015). Laporan Tahunan Kementerian Koperasi Dan Usaha Kecil Dan Menengah Tahun 2015

Lund, M. (2013). Cooperative Equity and Ownership: An Introduction is published by the University of Wisconsin Center for Cooperatives.

Mazzarol, T. (2016). Co-Operative Enterprise: A Unique Business Model?. Paper Presented At Future Of Work And Organisations, 25th Annual Anzam Conference, 7-9 December 2011, Wellington, New Zealand. Retrieved from https://www.researchgate.net/publication/235432100.

Nasution, M. (2008). Koperasi Menjawab Kondisi Ekonomi Nasional. Jakarta: PIP \& LPEK.

Prastowo, A. (2012). Metode Penelitian Kualitatif dalam Perspektif Rancangan Penelitian. Yogyakarta. Ar-ruzz Media.

Sukidjo. (2008). Membangun Citra Koperasi Indonesia. Jurnal Ekonomi \& Pendidikan, 5(2), 193-203.

Suprayitno, B. (2007). Kritik Terhadap Koperasi (Serta Solusinya) Sebagai Media Pendorong Pertumbuhan Usaha Mikro, Kecil, dan Menengah (UMKM). Jurnal Ekonomi \& Pendidikan, 4(2), 14-35.

Tjakrawerdaja, S. (2014). Koperasi Indonesia. Jakarta: Universitas Trilogi.

Undang-undang Republik Indoneisa Nomor 25 Tahun 1992 tentang Pengawasan Koperasi. 